\title{
Republicans see private sector as holding key to growth of US science
} tion to encourage more research in the private sector are the best means to expand US science in the future, Robert Walker (Republican, Pennsylvania), new chairman of the House of Representatives Science Committee, said last week.

Walker was speaking after a packed hearing on Capitol Hill to which he had summoned the heads of the main federal science agencies to provide their respective visions for the next 20 years.

"I want to see resources for science grow in the total economy," said Walker. "That doesn't mean bigger government programmes." He promised to use his strong ties with the rest of the new Republican leadership in the House to win tax concessions for programmes he favours, such as private-sector space launches and the development of hydrogen-powered cars.

The hearing was the first chance for the agency chiefs of the Clinton administration to exchange ideas (or cross swords) with the new Republican Congress. Those present included Jack Gibbons, the President's Science Advisor; Dan Goldin, administrator of the National Aeronautics and Space Administration (NASA); Neal Lane, director of the National Science Foundation (NSF); Carol Browner, administrator of the Environmental Protection Agency and Ron Brown, the Secretary of Commerce.

Walker's committee has jurisdiction over most federal science and technology (with the important exceptions of biomedical and defence research). The pugnacious Pennsylvania congressman has also been asked by his friend Newt Gingrich, the Speaker of the House, to serve as vice-chair on the powerful Budget Committee, where he will exert strong influence on federal spending.

But the hearing suggested that, although money will be tight, Republicans on the Science Committee at least have no intention of allowing an all-out attack by fiscal
Washington. Tax incentives and deregula-

conservatives on the \$73-billion federal science and technology budget.

Gibbons may have captured the administration's expectations adroitly by quoting Samuel Johnson's phrase that when a man knows he is to be hanged, "it concentrates his mind wonderfully". But he must have been quietly impressed by the number of Republican congressmen whose questions implied that they had turned up chiefly to defend science and technology programmes in their districts.

Before an unprecedentedly large crowd that packed the hall for three hours while many more were shut outside, the testimony of the agency chiefs revealed or confirmed a number of important specifics. Dan Goldin, for example, while declining to discuss the pending administration budget proposal for the 1996 financial year, made it clear there will be no money yet for the construction of a \$2.5-billion wind-tunnel complex (see $\mathrm{Na}$ ture 370,$242 ; 1994)$. That will mean the automatic rescission of $\$ 400$ million appropriated for the complex by Congress last year.

Alone among the agency chiefs - and true to form - - Goldin accepted the commit-

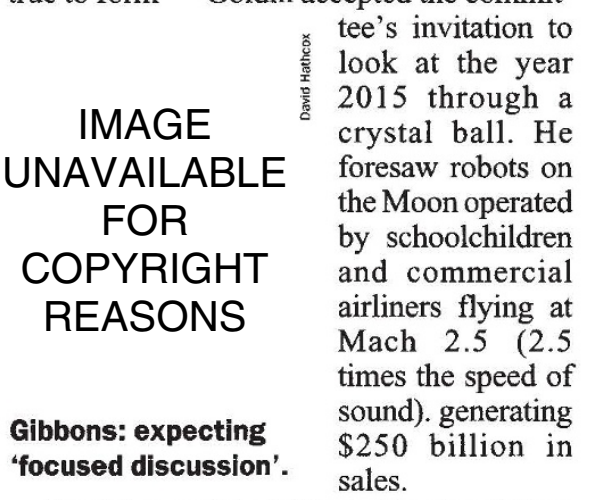

Neal Lane of the NSF declined to follow suit. He did not have "the slightest idea" what 2015 will look like, he said. Such predictions were "notoriously wrong". he

\section{ILL reopens after 4-year shut-down}

Paris. The world's most powerful neutron source, the 58.3 MW reactor at the Institut Laue-Langevin (ILL) in Grenoble, France, started up again last week after having been closed down for repairs for almost four years.

The reactor was shut down in 1991 after $\mathbf{2 0}$ years of operation, following the discovery of cracks inside the apparatus. The subsequent repairs, which cost FFr173 million (US\$32.2 million) and included replacing the entire reactor vessel, mean that the refurbished reactor is "al- most as good as new", according to ILL.

More than 1,400 researchers are expected to use the ILL this year. Almost 600 requests for experiments have been registered for the first semester alone, representing more than 2.5 times the amount of beamtime available.

But the number of beamlines has been reduced from 31 to 25 because of budgetary restrictions imposed by the United Kingdom, which, along with France and Germany, is one of the main contributors to the ILL. added. "Proud. But wrong."

Ron Brown was unable to convince Walker that his department's technology programmes are worth saving. They are "a criti-

\section{IMAGE UNAVAILABLE} FOR COPYRIGHT REASONS

\section{Goldin: envisages} robots on the moon. cal fraction of a per cent" of federal research and development, he said, and to lose them "would be an act of unilateral disarmament by the United States". But Walkersaid afterwards that the largest of them - the Advanced Technology Program - should be drastically curtailed.

Browner, whose Environmental Protection Agency is on course for a direct confrontation with the new Congress on several fronts, bluntly spelt out her differences with the Republicans on the issue of risk assessment. Under the proposals for this in the Republican manifesto, the Contract with America, she said, "we could not have banned lead in gasoline".

After the hearing, Gibbons said that he did not in fact expect US science to be hanged by the 104th Congress. "We are entering a period of focused discussion on these issues," he said. "The more we can talk about them, the more we will raise understanding of the fundamental value of science." Walker naturally concurred. "In my time in the House [there has never been] a leadership more enthusiastic about science and technology", he said.

It took Vernon Ehlers (Republican, Michigan) - until recently an active physicist - to raise scientists' concern about the intentions of both Republicans and Democrats. "I don't see the nation having the commitment to basic research that we had before. I see it faltering," he said.

George Brown (Democrat, California) and Tim Roemer (Democrat, Indiana) disputed the main thrust of the testimony from Gibbons, Goldin and Lane, - that in future they will be doing more science for less money. "Dan Goldin says we're going to see children playing with robots on the moon, but I just don't see it," said Roemer, an erstwhile science supporter and space station opponent. "We are going to have to make some tough cuts in these programmes. What about reality? How are you going to make these cuts?"

"You get efficient, you rationalize, and you measure outputs, not inputs," replied Goldin. "There's lots of room to eliminate lots of things we do." Colin Macilwain 